JOURNAL OF SECURITY AND SUSTAINABILITY ISSUES

ISSN 2029-7017 print/ISSN 2029-7025 online

2021 Volume 11

https://doi.org/10.47459/jssi.2021.11.9

\title{
CONCEPTUAL APPROACH TO MODERN COMMAND DEVELOPMENT IN SECURITY STUDIES
}

\author{
Piotr Baczar \\ Higher School of Criminology and Penitentiary Science in Warsaw, st. Wiśniowa 50, 02-520 Warsaw, Poland \\ E-mail: piotr.baczar@wskip.edu.pl
}

Received 15 November 2020; accepted 20 March 2021; published 30 March 2021

\begin{abstract}
The aim of the article is to present the basic aspects of command, functioning, decision-making, and responsibility. The author focuses on showing the broadly understood command system, especially in the course of implementing security tasks. Therefore, the content of the article presents an analysis of basic definitions, goals, assumptions, strategies of action for correctly perceived command based on the authority and genius of the person at the forefront of this process - the commander.

Command is seen as a process in which the commander imposes their will and manner of operation through orders, supported by an element of planning, organizing, anticipating, motivating, and controlling. The main and most important assumption of command is to create all possible circumstances to ensure maximum safety of execution of the task as well as for the entities participating in it. While analysing command as a process within a system, it should be emphasized that modern command system should be structured in such a way as to enable action to be correctly planned in a timely manner with a flexible and rapid response to changes in the situation. The ideal command system organized on principles of security should be able to gather relevant information continuously, comprehensively, selectively, and quickly. Command is the process of imposing the will of the commander and implementing their intentions, controlling the action and being responsible for decisions that often have very serious consequences. It is a responsible, multivariant and multi-entity process, which implemented skillfully, strengthens the position of the decision maker, as well as affects the morale of the performers and strives for the final success of the task.
\end{abstract}

Key words: command; security; management

Reference to this paper should be made as follows: Baczar, P. 2021. Conceptual approach to modern command development in security studies. Journal of Security and Sustainability Issues, 11, 131-139, https://doi.org/10.47459/jssi.2021.11.9

JEL Classifications: I31, I38

Additional disciplines: management; political sciences; sociology; education

\author{
And therefore a prince \\ who does not understand the art of war (...), \\ cannot be respected by his soldiers, \\ nor can he rely on them
}

Niccolò Machiavelli

\section{Introduction}

Understanding the chain of command in its entirety, mastering the basic aspects of the command system, and being able to properly manage its continuous process is an art that cannot be learned from theoretical books and not entirely reliable materials. Command is an extremely important and difficult element of management [from Polish 'kierowanie', hereinafter referred to as leadership to distinguish it from Polish 'zarządzanie' also referred to as management], affecting the ensuring of safety in a measurable and direct way. 
In recent years, a wide variety of studies on management and leadership over both individuals and entire countries have appeared (e.g. Lincényi, Čársky, 2021; Kriviņš et al., 2021). The subject has become not so much "fashionable" as desirable and needed in many scientific fields and aspects of everyday life, starting from running your own business and company and ending with prospering in a large corporation and making strategic decisions (e.g. Laužikas, Miliūtè, 2020). Authors and experts very often present the "decision-making theory" in various configurations and try to find the optimal solution for effective operation in this area. Management and leadership are very often associated with one more term, often overlooked in literature, and the multitude of studies on the subject is far too small.

A specific form of leadership is command. Perhaps this is due to the difficulty of the subject being addressed and thus the responsibility for the complex and relevant content related to this topic. Although command is regarded as a "basic form of human leadership", in its complexity it is not a simple process and, as it will arise in the course of further deliberations, it cannot be carried out by persons who do not have adequate knowledge and predispositions in this regard.

To understand the specific subject of command itself, it is necessary to answer the questions that will lead us to the understanding of presented issues, namely: How is command understood in the light of literature and practical basis? What factors influence the command process and its final success? What projects should the commander carry out to ensure the safety of the task? These are just some of the issues and problems related to the extensive topics which the author will try to answer as well as lead to a wide discussion and exchange of experience on the subject of command.

\section{Command and control}

To answer the above questions, we need to look for the most appropriate definition of command itself, so as not to make a mistake at the level of comparing it with management and leadership. Very often these terms are used interchangeably (Mołek, Stec, \& Marciniak, 2011), which leads to generalizations, the use of a mental shortcut, and incorrect understanding of reality ${ }^{1}$. However, distinguishing between these terms is necessary ${ }^{2}$ in an attempt to create a good structure, a well-functioning organization, and, in the case of command, an organizational unit. Management is primarily the answer to the question: Where are we going? It provides a global, broad view of setting goals for organizations through strategic decisions at a high organizational level. Leadership is the "lower-level management", based on the question: How? How to assign tasks to individual organizational groups to achieve the goal. The thematic extent of management and leadership, as already noted in the introduction, is very broad and it is not the main problem of the discussed subject, but it should be noted that the crisis management process already has a great many characteristics in common with command. "Crisis management is nothing more than good management under pressure for time and relevance of decisions. Adrenaline can circulate faster, but it only helps to concentrate better. Good managers thrive in tense situations (Prońko, Wiśniewski, \& Wojtuszek, 2006), and they are the ones who prove themselves in crisis situations". In the case of command, a very important factor is the "time limit" or more precisely, the result of the decision made in the shortest possible time unit. Command can be defined as a function ${ }^{3}$, that must be exercised more or less continuously for forces to exist and work towards a goal. Important factors characterizing the process (function) of command are existence and operation ${ }^{4}$.Without any of these factors, command becomes ineffective and pointless at the same time. The continuity aspect of command is also a distinguishing feature from the leadership, command is often seen as a process in which the commander imposes their will and manner of operation through orders, supported

\footnotetext{
1 An example of a homogeneous perception of management and management is the following definition: The concept of management (leadership) can simply be described as the art of achieving the set objectives by using means at one's disposal. Today, it is defined as a managerial activity covering areas of activity such as planning, organizing, deciding, motivating, supervising, and controlling.

2 As in English both 'zarządzanie' and 'kierownictwo' are referred to as 'management', the term leadership has been applied to distinguish these terms. Management defines at the same time the leadership, the management board, upper management, directors, and ruling.

3 Just as leadership is one of the basic functions of management.

4 On factors influencing the command process more in the further part of the paper.
} 
by an element of planning, organizing, anticipating, motivating, and controlling. Command is a quick response to the situation. "The activities of the commander and people cooperating with him; combat preparation and conduct, military training and administration of a military unit; also a department of the art of war dealing with these matters. During the war it consists in: ensuring constant combat readiness and the power of the moral and political state of the army; making a decision in the language version and submitting it to contractors, organizing and constantly maintaining military cooperation, organizing and ensuring useful security and controlling all military orders and activities. In peacetime, it consists in managing the process of training and educating subordinate soldiers, administering the entrusted unit and maintaining combat readiness. The essential content is to decide on the website, weapons and equipment both in combat and operation as well as in training work. The functions are performed by the commander himself (in the lower chain of command) or with the participation of the staff, he participates in the development of decisions, planning and securing the fight (operation) and in managing the military in the course of combat operations. The higher the command level, the more the scope and the differentiation of the nature of the command functions expand, and the staff participation in it increases. The basis for commanding troops is a decision made by the commander in connection with the received combat evidence (Bordziłowski, 1967) or on his own initiative". The dynamics of the action greatly affect the safety and effectiveness of the implemented operation-of an action. When carrying out an attack, the most important thing is the speed of decisions and the flexibility of operation. The shorter the time it takes to make a specific, accurate, and safe decision in response to a situation, the more intuitive form is assumed by the "command process" and that will make command simply effective. This is what modern command is aiming for, for the pressure of time not to have a disheartening effect on the commander, only a motivating one.

During the elapsed time, all activities must be undertaken which will lead to the implementation of the main objectives of the command consisting in:

- an assessment of the risk by determining its nature and expected direction of development,

- the identification and concentration of forces and measures necessary for the safe execution of the task,

- the identification of the tasks and organization of the various actors involved in the implementation,

- defining the general intention of the way in which the task is to be carried out by outlining options for the action,

- the organization of command, communication, and information circulation system,

- coordinating the preparation of logistical, medical, and technical security,

- coordinating and supervising the implementation of the operations.

In the author's opinion, the main and most important assumption of command (in addition to those mentioned above) is to create all possible circumstances to ensure maximum safety of execution of the task as well as for the entities (persons) participating in it.

Command consists in:

- getting acquainted with the current situation and risk assessment mainly by establishing the facts of the existing situation and its expected development,

- preparing variants of attacks,

- defining tasks for individual groups performing tasks, appointing commanders of individual groups,

- determining "own forces" and "enemy forces" in the area of operations, concentration of forces and resources necessary to remove the threat,

- organization of the command unit, appointment of the deputy commander and other functionaries,

- organizing the command and communication system by appointing appropriate persons,

- providing logistic security (medical, fire, specialist depending on the risk),

- supervision and coordination of implementation activities in accordance with the assumptions of the attack,

- ongoing cooperation with the services involved in the implementation, 
Command is thinking, analyzing, and acting - all simultaneous and dependent on each other. Command is so strongly linked to other, numerous factors, shaping the end result of victory, that it becomes impossible to provide one or more "prime" rules, which should govern the structure and mode of operation. The ideal command system, like Plato's state, exists only in heaven.

The guiding principles governing the command are constant, but the way in which they are achieved is and should be variable. The variability and unpredictability of tactics (Koziej, 2011; Kopaliński, 1985) ${ }^{5}$ is a testament to the cunning and maturity of the commander. One should not move constantly over the same task options and rigidly stick to the imposed procedures because: "The strategy of the winning battle cannot be repeated (Tzu, 2013). The number of possible reactions is inexhaustible.". Tactics should be adapted to the prevailing circumstances, depending on the formation, time, and "command model". The ways in which the intended objective is achieved are different, just as command itself is viewed in a variable way.

"Command - the directed operations of the commander (Police Commander in Chief, 2014), carried out within the framework of police activities, ensuring the high capacity and resources of the Police forces to achieve the objective of these activities and characterized by particularly efficient, one-man decision-making and taking accountability, precise distribution and control over the course of action". It is carried out in the preparation and fulfillment of tasks in the case of danger to life and health. As the above definition indicates, an important element of command is to take responsibility for the decisions taken. And here, unfortunately (as opposed to leadership), the result of a wrongly made decision may be exposure to the loss of life and health of "contractors", subordinate officers implementing the orders. In the case of leadership, the effects are usually material.

Command itself is a process that takes place within a system. A process that uses the collected information to coordinate people and measures to complete tasks. The aim of the command system is to gain certainty as to the effectiveness of each factor, coordinated with each other to achieve the intended optimal result. The modern command system (Makowiec, Mroszczyk, 2012) should be structured in such a way as to enable action to be correctly planned ${ }^{6}$ in a timely manner with a flexible and rapid response to changes in the situation.

To achieve effectiveness and certainty of operations, one must first have all the useful and practical information. However, the more information there is, the more likely it is that wrong decisions are made due to distinguishing between relevant and irrelevant, true and false information. Clausewitz's statement contains a lot of truth: "many of the messages received in war are contradictory, even more are false, and most are uncertain." It would seem that the solution to this dilemma is impossible, unless we cite Napoleon, who spoke of a "higher understanding" based not only on training and practice, on rational calculation, but on intuitive judgement. Encountered war situations, a combat event based on the same facts and information held by different commanders, will be resolved by them in different ways, and any solution can prove to be effective.

The concept of "excess information" is not thriving in command. An effective and wise commander can distinguish between true data, which provide a picture of the real situation, and information that is insignificant, which only interferes with the decision-making process. A large number of useful messages will affect the speed and relevance of the issued orders, the achievement of the desired goal.

Surely the main purpose of command is to know the plans of the enemy, and then take all measures to make these plans prove unrealistic and remain in the realm of dreams. To defeat the enemy, one needs to first know and familiarize oneself with the enemy's standards, schemes of action. The main factors (often perceived as responsibilities) influencing this process are the assumptions that:

- the command must coordinate and organize everything that the subordinate forces need to exist (logistical needs, medical needs, etc.)

\footnotetext{
5 Tactics - the term itself comes from Greek and literally meant ordering, putting in a battle formation. In the general sense, tactics is the method of operation, ability to use forces at the disposal to achieve set goals.

6 Planning of the operation is the most important phase of the command process, it decides on the efficient use of forces and means in a fight, and in a result on the completion of the task.
} 
- the command enables the relevant task to be carried out in a fast, continuous and secure manner (planning and supervising activities).

Both factors: existence and operation, are closely interconnected and the chain of command cannot exist and be properly implemented without them. Command in practice covers a number of aspects that depend on each other. Important here is also the collection of information about one's own and enemy forces, about the structure of the terrain and weather conditions. All information is collected, stored, segregated, appropriately selected, presented. On the basis of the information, an alternative, optimal way of carrying out the task is developed. The ideal command system should be able to gather relevant information continuously, comprehensively, selectively, and quickly. It is important to be able to separate truth from falsehood and essential from irrelevant things and then to present them competently in a clear, detailed, and comprehensive manner. The ability to present the results and analyze the possessed information is undoubtedly the most important personality trait of the commander carrying out a battle task. After all, in the final phase, the "contractors" are a reflection of the commander's implementation thought.

Further factors influencing the command process include:

- the development of technology,

- the total number of subjects under command (increasing the complexity of command).

The process of proving is understood as a cycle of organized action, expressed as an algorithm for the identification and preparation of actions - a logical arrangement of consecutive and dependent stages and activities. The command process is structurally divided into many phases, stages and activities performed at all levels of command. It is also consistent with the basic assumptions of the theory of organization and management, in particular - decision making.

The development of technology forces a continuous progress: both of the command process and of those deciding on the direction of implementation operations. Command tasks are age-old. A commander from the Stone Age, possessing data and very diverse resources, was just as much a leader as a modern-day commander. Generally smaller, simpler and slower in action, the commander's tasks were also simpler to accomplish. Just as command functions are usually not subject to change, the resources at the disposal are now a result of long and continuous development.

The nature of a task is not the only determinant of the amount of information required to complete a task. The structure of the institution is important, the more developed it is (a large number of intermediate actors, departments, organizational units), the greater the number of levels of command, the greater the amount of information processed, the greater the possibility of distorting information and, ultimately, the wrong decision, the consequences of which will be suffered by the commander.

The factors mentioned above, they all perform a significant role in the entire command process aimed at achieving the final success, impossible without a connecting and consolidating element that is the commander themselves. For them to perform their duties well, they must be seen as a charismatic genius with the right skills and a predisposition to realize their thoughts. The charisma of the commander (the basis of charismatic leadership), "that is, the special personality traits of the leader (Griffin, 2005), allowing them to influence others", allows them to complete the command process in its entirety and at the same time ensures the safety of their subordinates.

Command is closely related to the activity of the commander who fulfils his role by the command functions understood as a complex of tasks and undertakings, assumed or actual, carried out by individual functional persons or organizational units within the command.

One of the commander's main skills is to motivate their subordinates to act. To motivate subordinates, the commander themselves must be motivated or must deceive everyone around them all the time (moral forces). Motivation is seen as a willingness to take specific action at all levels of command, it drives the entire decision- 
making process and, combined with efficiency and determination, creates the perfect process. "Commanders must have the ability and determination to perform a combat task (Jałoszyński, 2011). They must be able to subordinate their subjects in times of failure and danger".

The commander's knowledge and leadership skills largely depend on their talent and predisposition, but not only. Theoretical (learning) and practical (skills acquisition) preparation is also an important element. Undoubtedly, this is a lengthy process, and experience and practical skills are acquired over time. No amount of learning can replace genius and intellect.

The advantage over the enemy is obtained through the intellectual abilities of the commander. The art of proper command creates an advantage, a mental advantage, as well as the real one on the battlefield. It is not only the size of the army, technological development, tactical domination that determine the final victory. Each commander should have character and personality; wisdom, credibility, kindness, courage, but also austerity. A good commander is one that requires a lot from their people, but also from themselves. They have a wellunderstood sense of mission and are respected by their subordinates. They should be versatilely talented and effective in their actions. "The generals are characterized by wisdom, credibility, kindness, courage, and austerity (...), if the general is comprehensively talented (Tzu, 2013), the state will be strong". Unfortunately, without a competent commander endowed with the right qualities and abilities, command efficiency can deform, and as a result, the set objectives and tasks may not be achieved.

The most important assessment of the commander's actions is to see them through the prism of effectiveness, that is, the ability to achieve the assumed and set goal. Analytical, substantive, and social skills can enhance the commander's effectiveness when they are linked to professional and life experience. The tool of an effective commander and the way of conveying their own combat and strategic ideas are orders that fulfill the mechanism of operation of the command system.

Orders must be short, clear, and unambiguous, and subordinates must receive everything they need to know, but no more. The excess of contained content in the order complicates the process of accomplishing the task and unnecessarily introduces a factor of intricacy. The conciseness and relevance of the order results in the speed of its execution and the certainty of subordinates in understanding the commander's intentions. "Psychological disorientation basically arises from the commander's sense (Liddell Hart, 1959) that they fell into a trap". Such a situation in the short term will lead to destabilization of the situation and loss of control over people and in consequence of events that are to happen. It will put all implementing entities at risk. The main objective of modern command should be to maintain the full combat capability of the unit by ensuring safety of those performing the task. It is not the execution of a given order (often erroneous or imprecise) at all costs, but the calculation of frequently unnecessarily taken risks, which can result in loss of life or health of the implementers. The main principle of command should be the principle of maintaining the safety of all participants in the event. The safety of the undertaken actions should be the commander's directive, affecting the choice of tactics and the type and scope of use of forces and measures. A conscious sense of safety of the persons carrying out the task affects the effectiveness of actions, caution and accuracy of achieving the goals.

An irresponsible commander is a threat not only to the success of the combat action, but mainly to the task performers themselves. "A little imagination! Its lack fools confuse with courage (Petelicki, Komar, 2013). When a fool has power over other people, you have to be afraid...". Imagination and responsibility, ability to predict the future, developments, perspective, and appropriate competences - these are the next characteristics of the decision-maker and organizer of the combat. But are these qualities only for the commander? Are performers just "implementers" of the leader's thought? In the chain of command, everyone bears the consequences of their conduct and decisions. "There are some like that. It is known that everyone is looking for some opportunity to succeed. One is courageous, the other stands out for their wisdom (...). But woe to a commander who surrounds themselves with bootlickers, rather than rewarding independent-minded people. Woe, as when they believe in their infallibility, they will enter the path of mistakes threatening the lives of soldiers and the security of the state". 
To effectively lead the command process, one needs a genius leader and subordinates who implement orders, but also think independently and are able to make integral decisions in an emergency and in unexpected situations, when it is not possible to receive guidance from the commander. Command is governed by certain principles (positive and negative), compliance with which will ensure the effectiveness and safety of operations.

Positive principles include:

- determining the objective according to the possessed resources,

- an objective regarded as an overriding need,

- selecting the direction (or manner) of action least expected by the opponent,

- using the direction of the least resistance,

- choosing the path of action allowing to jeopardize alternative targets,

- respect for the flexibility of the plan and the military grouping so that it can be adapted to the circumstances.

Negative rules addressed to the commander include:

- do not attack with the main forces until the enemy is on guard,

- do not resume the assault in the same direction (Liddell Hart, 1959) or in the same grouping.

The principles of command emphasize the use of "tactical subterfuge", a force perceived as a vicious circle or rather a spiral is not the domain of correct thinking and carrying out the task to be performed. The real pinnacle of perfection and the phenomenon (genius) is to defeat the opponent without taking up the fight. Achieving success without unnecessary risk and exposing people to loss of life or health is the excellence and maturity of command.

Strength (impact, attack) directed straight at the enemy's main potential very often results in large losses of one's own. Once - a deception, today -a surprise - decides about gaining an advantage over criminals. Through the non-standard manner of the solutions and the speed of the carried out implementation activities, the task is completed. "War is the Tao of deception" (Tzu, 2013). The end success is often the determinant of applying the following thoughts: "Attack when they are unprepared, go where they don't expect it" (Tzu, 2013). Deception is the essence of victory. It causes confusion and is at the root of manipulating the enemy. Most effective actions are based on surprise and outsmarting the opponent.

All aspects and secrets of command cannot be accurately described and determined; included in a short study or in an extensive book. Masters of this trade learn for years not in theory, but on the battlefield, learning its most practical secrets. The best command system at its head should have a tactical genius who has mastered the basic organizational elements, can use the latest technical means to gain an advantage, knows the procedures of action on the battlefield, skillfully acquires, processes, and analyzes information necessary to gain domination over the opponent and to plan variants of action, can accurately issue orders by means of communication or directly, controls the course of events, and reacts according to needs. Just as strategy is the sum of tactical victories, command is the ability to tactically gain dominance. Achieving a strategic advantage and controlling tactical inequality - this will ensure the final success and achievement of the set goal.

The command process is treated as a repeated informational and decision-making cycle of actions aimed at the most effective preparation and use of forces and resources, both permanent and temporarily allocated. It consists in the continuous collection and processing of information and cyclical processing of it into appropriate decisions, which are transferred in the form of tasks contractors. It should be remembered, however, that information necessary in the event of a combat situation for an effective response includes: enemy forces and means, number and degree of weaponry, location in the field, appropriate starting position for the attack, weather conditions, other circumstances affecting the safety of the operations. One of the most important factors determining the effective response to the situation is the determination of the time and place of the attack. In the case of hostilities as well as counter-terrorism operations, these are factors that influence the de-escalation of the event. In response to such threats, it is important to strike at the right time and at a certain point. 
Adequate estimation of forces and resources. Attacking only if victory is certain. Correctly estimated needs, allow determining how many people and what means will provide one with the final victory. Sending excess soldiers and equipment into battle is a waste of resources. An indispensable condition for smooth command is the precise control over the forces and respect for the advisability of actions aimed at preserving the economy of the forces. Combined with surprise and strategic and combat initiative, they create the ideal model for an effective command system.

To sum up the considerations made so far, it should be emphasized that command must not be limited only by knowledge of the basic principles on the battlefield, but above all by the implementation of the practical ability to subjugate the enemy to one's will. Command shall be designed to enforce the rational management of the resources allocated to achieve the set objectives. The essence of command comes down to constant, consistent action to subjugate the army to perform the combat task with the least losses and within a certain time frame. The commander's success depends on the competence, skill, ability, and potential they possess, so they must consistently nurture their qualities so that they are not forgotten and learn to use them for a good purpose.

\section{Conclusions}

Command is the process of imposing the will of the commander and implementing their intentions, controlling the action and being responsible for decisions that often have very serious consequences. It is a responsible, multivariant and multi-entity process, which implemented skillfully strengthens the position of the decision maker themselves, as well as affects the morale of the performers and strives for the final success of the task.

In order to properly implement the command process, one should aim at the optimal use of the forces and resources at the disposal, skilfully dispose of them and correctly assign them. By knowing the theoretical aspects and improving practical skills, one should strive to achieve success, remembering at the same time that the most important task is the safety of people. Security perceived through the prism of skilfully conducted combat operations and well-thought-out decisions. It is safety that should be the main tenet of modern command.

\section{References}

Bezpieczeństwo narodowe [National Security I], Publisher: National Security Bureau, Warsaw 2011.

Bordziłowski, J. Mała encyklopedia wojskowa, t. 1, Warszawa 1967, p. 320-321.

Griffin, R. W. Podstawy zarządzania organizacjami [Foundations of organizational management], Polish Scientific Publishers PWN, Warsaw 2005, p. 576.

Grom siła i honor z generałem Stawomirem Petelickim rozmawia Michat Komar [Grom strength and honor, Michał Komar talks to general Stawomir Petelicki], Wydawnictwo Literackie, Warsaw 2013.

Jałoszyński, K. Jednostka kontrterrorystyczna - element działań bojowych w systemie bezpieczeństwa antyterrorystycznego Counterterrorism unit - an element of combat operations in the antiterrorism safety system], Police Academy Publishing House, Szczytno 2011, p. 110.

Kopaliński, W. Stownik wyrazów obcych i zwrotów obcojęzycznych [Dictionary of foreign words and expressions], Warsaw 1985, p. 416.

Koziej, S. Teoria sztuki wojennej [Theory of the Art of War], Bellona, Warsaw 2011, pp. 34-35.

Kriviņš, A., Teivāns-Treinovskis, J., Tumalavičius, V. 2021. Issues of state and national security: Religiously inspired terrorism in the Baltic States: internal and external factors. Insights Into Regional Development, 3(1), 65-79. http://doi.org/10.9770/IRD.2021.3.1(4)

Laužikas, M., Miliūtè, A. 2020. Human resource management effects on sustainability of high-tech companies: what Lithuania and South Korea can learn from each other. Insights into Regional Development, 2(2), 562-579. https://doi.org/10.9770/IRD.2020.2.2(5). 
Liddell Hart, B. H. Strategia - działania pośrednie [Strategy - indirect action], Ministry of National Defense Publishing House, Warsaw 1959 , p. 359.

Lincényi, M., Čársky, J. 2021. Research of citizens' behavior in a political campaign in searching for and monitoring political advertising in The Slovak Republic. Insights into Regional Development, 3(1), 29-40. https://doi.org/10.9770/IRD.2021.3.1(2)

Makowiec, P., Mroszczyk, M. Taktyka walki w terenie zurbanizowanym [Tactics of Urban Warfare], Difin, Warsaw 2012 , p. 192.

Mołek, W., Stec, K., Marciniak, K. Zarządzanie kryzysowe w systemie kierowania bezpieczeństwem narodowym [In:], Bezpieczeństwo narodowe I [National Security I], Publisher: National Security Bureau, Warsaw 2011, p. 53.

Order no. 23 of the Police Commander in Chief from the $24^{\text {th }}$ of September 2014 on the methods and forms of preparation and implementation of Police operations connected to crisis situations.

Prońko, J., Wiśniewski, B., Wojtuszek, T. Kryzys i zarządzanie [Crisis and management], Publisher Wyższa Szkoła Administracji, Bielsko Biała 2006, p. 158.

Sun Tzu, Sztuka Wojny [The Art of War], HELION, Gliwice 2013.

Piotr BACZAR is Assistant Professor at the Higher School of Criminology and Penitentiary Science in Warsaw, doctor of social sciences in the discipline of security sciences, graduate of the Police Academy in Szczytno, author of articles on anti-terrorism, former officer of the Independent Counter-Terrorism Police Sub-Unit in Bialystok.

ORCID ID: https://orcid.org/0000-0002-8778-7875 